\title{
MACRO-REGIONAL ANALYSIS OF TOURISM ENTREPRENEURSHIP ENVIRONMENT IN BALI: A DESCRIPTIVE STUDY
}

\author{
Donny Susilo \\ Department of Business Administration \\ Asia University, Taiwan \\ Donnysusilo777@gmail.com
}

\begin{abstract}
Bali has always become a world-class famous tourism destination since a long time ago. Entrepreneurship development in Bali is urgently required because it can create job for local people and maximize the utilization of local resource for regional growth and development. This research aims to understand tourism entrepreneurship environment in Bali based on macro-regional analysis. This research used PESTEL framework and secondary data from various sources to analyze external environment of Bali as a place to develop tourism entrepreneurship. This research also conducted seasonal analysis from secondary data to understand characteristic of tourism market in Bali. The research founded that governments actively promoted Bali as world-class tourism destination, while at the same time provided grant for green project. Through their investment coordinating board, governments also helped investor to enter Indonesia market easily and conveniently. In economic aspect, tourism industry growth is seasonal but prospective because the economic growth in Bali is visibly good and stable. While setting up business in Bali needs basic knowledge in local Hindu culture, the technology infrastructure in Bali still needs improvement especially related to internet speed. Green project is important because Bali has significant environmental issue on recently, which also becomes opportunity for entrepreneurs to innovate. The protection law and legal standing for entrepreneurs in Bali is basically available but still need improvement, especially in the field of startup taxation, garbage reduction and green project regulation.
\end{abstract}

Keywords: Bali, Tourism Industry, Entrepreneurship, Development JEL Classification: R11, Z31, 025

Copyright (C) 2020, International Journal of Economics, Business and Entrepreneurship | IJEBE | FEB-UNILA

\section{INTRODUCTION}

Bali has always become one of biggest contributors to tourism industry in Indonesia. Government paid a lot of attention its tourism development because of its popularity as world classed tourism destination. Despite its market attractiveness, the contribution of tourism development in Bali to wealth of its local resident remains questionable, especially because of high price in property that causes lack of motivation for people to set up their own business in Bali.

Entrepreneurship development in Bali is essential because it can create job for local people and maximize the utilization of local resource for regional development and competitiveness. Regional competitiveness becomes major concern for every local 
government as it is considered to be region ability to compete with one another to grow and prosper in economic term. Tourism industry in Bali needs to be accommodated with more variety of product and service and therefore tourism development and entrepreneurship have mutual benefit and are connected with each other. This research aims to understand tourism entrepreneurship external environment in Bali. The benefit of this research is to provide information for tourism entrepreneurs or people with entrepreneurial intention in tourism industry so that they have fundamental knowledge to propose appropriate strategy and business model when setting up business in Bali. This is also a contribution to tourism entrepreneurship literature and become base to make further research in tourism area.

\section{LITERATURE REVIEW}

\section{Entrepreneurship}

According to Milla (2013), the definition of entrepreneurship from a conventional perspective can be interpreted as the ability to create new businesses or different businesses that are carried out individually or in groups independently and innovatively. Furthermore, she also said that entrepreneurship can be divided into two; firstly, social entrepreneurship and secondly, non-social entrepreneurship. According to Reginald and Mawardi (2014), social entrepreneurship is an entrepreneurial activity that aims to solve social problems in society and not solely to seek profits which are the characteristics of social entrepreneurship including the creation of social value, innovation, civil society, and the existence of economic activity. On the other hand, nonsocial entrepreneurship is an entrepreneurial activity that aims to get profit. Based on this understanding, entrepreneurship is also considered a solution in overcoming the nation's economic problems. This research discussed about non-social entrepreneurship which aims to make profit and therefore can contribute to regional economic growth and development.

\section{Tourism Industry}

Tourism is a trip taken by humans to an area that is not their place of residence in at least one night with the purpose of traveling not to earn a living, income or livelihood at the destination (Damanik and Weber, 2006). They further said that the tourism sector is one of the supporters of tourism activities both services and tourism products. The tourism sector stakeholder can be classified into six main groups, namely:

1) Direct actors

It includes businesses that offer services directly to tourists as their needs such as hotels, restaurants, travel agencies, tourist information centers and attractions.

2) Indirect actors

It includes businesses that specialize in products that indirectly support tourism, such as handicraft businesses, tourist guide sheets and others.

3) Supporting tourism services

This group is a business that does not specifically offer tourism products and services but often relies on tourists using these services and products, such as photography service providers, beauty services, sports and so on. 
4) Government

Government has authority in regulating, providing and allocating various infrastructures related to tourism needs and making macro policies that guide other stakeholders in playing their respective roles. Macro Economics examines the economic phenomenon as a whole or broadly. It can include inflation, unemployment, national income, employment opportunities, unemployment, fiscal policy, monetary policy, balance sheet, payments, investment, and economic growth.

5) Local people

This group refers to indigenous people who live in tourist areas, become one of the key players in tourism, because in fact they are the ones who will provide most of the attractions while determining the quality of tourism products. Therefore their role is mainly seen in the form of providing accommodation and guiding services and providing labor.

6) Non-Governmental Organizations (NGOs)

Many Non-Governmental Organizations (NGOs) both local and international carry out activities in tourist areas, even a long time ago before tourism was developed. These non-governmental organizations have carried out activities both in particular and in collaboration with the community.

\section{PESTLE Analysis}

PESTLE is abbreviation of Political, Economic, Social, Technological, Environmental, and Legal. According to Williams (2010), PESTLE is a tool that helps us to know the big things that are happening. These macro-economic factors are something like an economic crisis, or an aging population, which cannot be changed by business. Identifying the influence of PESTLE greatly helps the method in drawing conclusions related to the external environment in which the business operates. However, this must be followed by consideration of how the business should act in response to these influences. PESTLE analysis is an external analysis when a company conducts market research and provides a broad picture related to aspects of the macro-environment that companies must consider. These aspects are:

1) Politic Aspect

Politics consists of regulations related to employment, environmental regulations, tax provisions, and political stability. Political factors that are analyzed and diagnosed by most companies include minimum wages, price control, opportunity to work together for everyone, tax regulations and environmental protection, international trade regulations.

2) Economy Aspect

The economy impacts the purchasing power of potential customers and the cost of capital of a company. Examples are economic growth, interest rates, currency rates, and inflation. Specific economic factors that are analyzed and diagnosed by most companies include economic regulation, monetary policy, government spending, unemployment policy, business cycle stages and financial policy.

3) Social Aspect

Social consists of demographic and cultural aspects of the macro-environment. This factor impacts on customer needs and potential market sizes. Examples are health awareness, population growth rates, age distribution, career or occupation, and safety concerns. Social factors that are analyzed and diagnosed by most companies 
include income distribution, demographics, labour, lifestyle changes, work attitudes and education.

4) Technology Aspect

This factor can reduce barriers to market entry, reduce the minimum level of efficient production, and influence the decision to outsource. This aspect includes research and development activities, automation, technological incentives, and the level of technological change. Technological factors that are analyzed and diagnosed by most companies include the discovery and development of new technologies, speed of technology transfer, cost and use of technology, changes in science and the impact of technological advancements.

5) Environment Aspect

The environment consists of weather and climate change. This change can affect many industries, such as agriculture, tourism and insurance.

6) Legal Aspect

Legal related to the rules or laws of the environment around the company operates. This change in law will certainly change the behaviour of the company.

Figure 1. PESTLE Framework
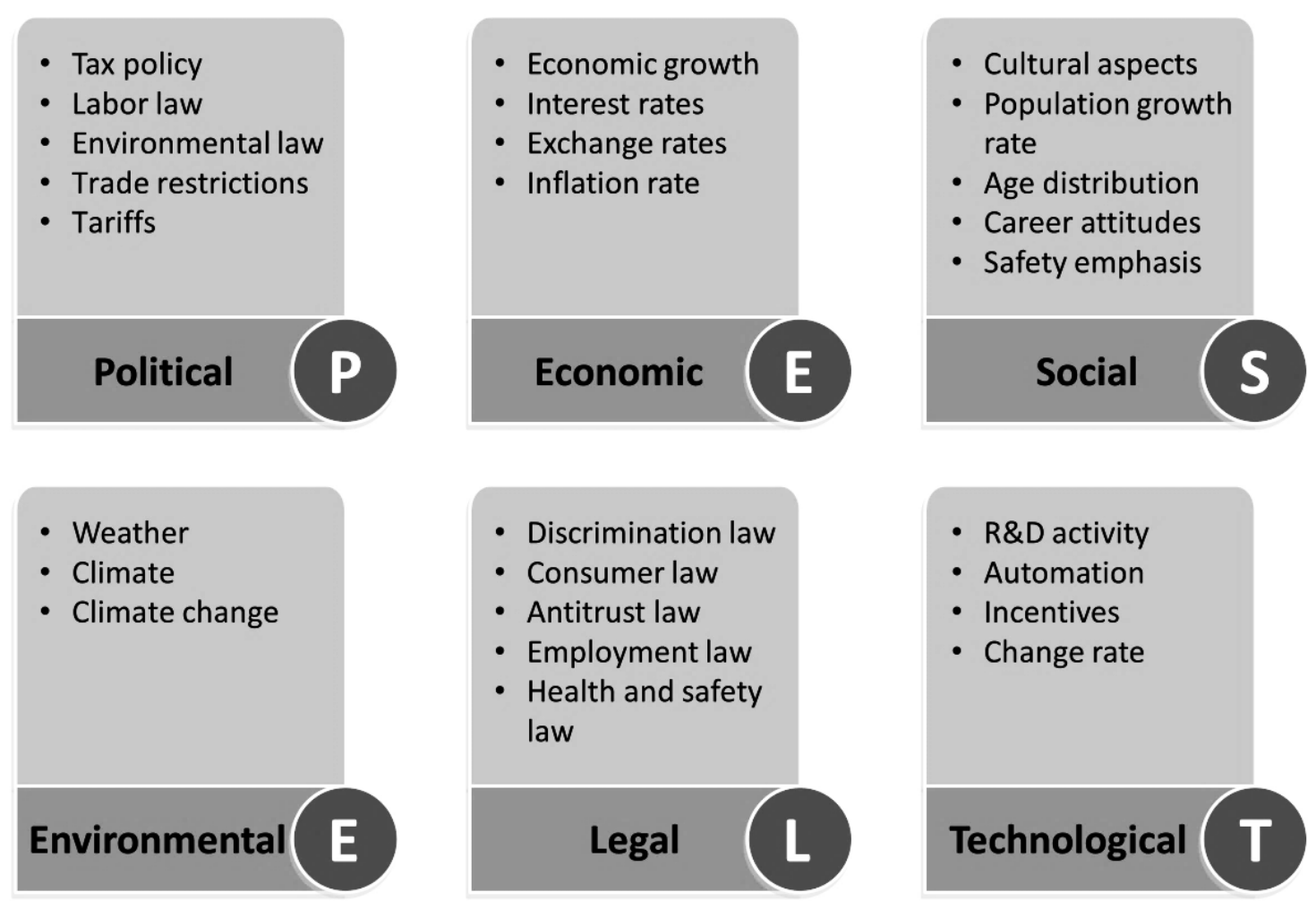

Source: Williams (2010)

\section{METHODS}

The type of this research is descriptive research with review approach. In order to provide macro-regional analysis of tourism entrepreneurship environment in Bali, this research used PESTEL framework which was originally invented by Aguilar in 1967 
and secondary data from various sources to analyze external environment of Bali as a place to develop tourism entrepreneurship. The PESTEL tool is very useful to understand the overall picture of the environment of where the business operates, so that opportunities can be taken and risks or threats can be minimized. This tool is also useful to provide understanding of all potentials and risks associated with business in politic, economic, social, technology, environment and legal aspect.

\section{RESULTS AND DISCUSSION}

\section{Politic}

The seriousness of Indonesia government to promote Bali as main international tourist destination is out of question. It is line with national focus on developing tourism in Indonesia. New Bali campaign was introduced which mainly discussed about developing 10 new tourism areas all over Indonesia that will be famous like Bali in the future (Dimyati, 2019). Wonderful Indonesia is the brand of ministry of tourism to promote Indonesia tourism to the world (Irawan, 2018). It indicated that choosing Bali as the place to set up business is strategic option with rapidly growing potential market for tourism.

Government also released regulation no. 21 in 2016 related to free visa policy to 174 countries in the world to accelerate the tourism industry growth (Ariyanti, 2015). The policy was expected to increase foreign direct investment from tourism and also increase the number of incoming tourists from other countries, which make market in Bali becomes prospective. In 2017, President Jokowi released Perpres (president instruction) no 91 aimed to increase investment in Indonesia. The president instruction assigned a team of people who were in charge of increasing service quality, supervision, problem solving quality and online registration in central and regional Indonesia Investment Coordinating Board. It was expected to make investment procedure easier in strategic sectors including tourism industry. The policy was also to eliminate corruptive behavior that caused fear for entrepreneurs who wanted to start up their business in Indonesia (Fauzie, 2017).

Meanwhile, government of Bali kept increasing their investment target from both local and foreign investors, for 2018 investment target was increased to be 18.37 trillion rupiah more than national target which was only 12 trillion rupiah (Parwata, 2018). Indonesia itself had provided grant to support entrepreneurship in Indonesia. Through its Investment board, government launched funding to push more green projects and provided special funding named green investment which reached 100 Billion USD in 2019 (Gumelar, 2018). This provided opportunity for tourism entrepreneurs in Bali to make proposal because Bali has a lot of environmental issue such as sea and air pollution on recently. In education, Government provided support to increase number of co-working spaces in college and university especially stated institution that mostly offer free of charge co-working space, business incubation and acceleration by tight selection process, it can help to increase the number of new entrepreneurs (Irawan, 2018).

\section{Economic}

Along with increasing number of tourists in Bali, need and demand for accommodation was also increased. It was confirmed that there was increasing demand 
more than increasing number of commercial housing for rental such as hotel, villa, guest house and others. The occupancy rate of star-rated hotels in Bali was 66.72 percent during June 2017. That means there was an increase of 4.81 percent compared to May 2017 which recorded 61.91 percent. It created market opportunity in tourism sector. The development of new hotel in Bali was dominated by 4 star hotel above while the growth of 3 star hotel below was decreasing up to 2020, the trend showed that new investors target middle up segment (Bali Government Tourism Office, 2018). However, when observing further the characteristic of hotel occupancy rate in Bali, it was seen unstable and seasonal. The occupancy rate of hotel in Bali was normally between 55 percent-65 percent in average but at some moments such as Eid Al-Fitr holidays, the occupancy rate can increase up to 90 percent, which is normal characteristic of tourism industry in general.

The graphic 1 below showed result of seasonal analysis for hotel occupancy in Bali 2014-2017. Seasonal analysis is intended to understand the trend and season where the sales is up and down, the study is fundamental to formulate appropriate revenue management practice to maximize potential income within a year. According to room occupancy rate (in percent) in Bali 2014-2017 from Statistical data release in Bali Government Tourism Office (2018), the peak season for room rental in Bali is around July-September, there is a slight down in March-April. This trend is stable from year to year. It applies to hotel along with other type of commercial room rental business such as villa, guest house, homestay, resort and so on. Therefore hotel entrepreneurship should anticipate and maximize its capacity in July-September period, price could be increased when the demand is high and there will be promotion strategy executed when the demand is generally low.

Graphic 1. Seasonal Analysis for Hotel Occupancy Rate in Bali 2014-2017

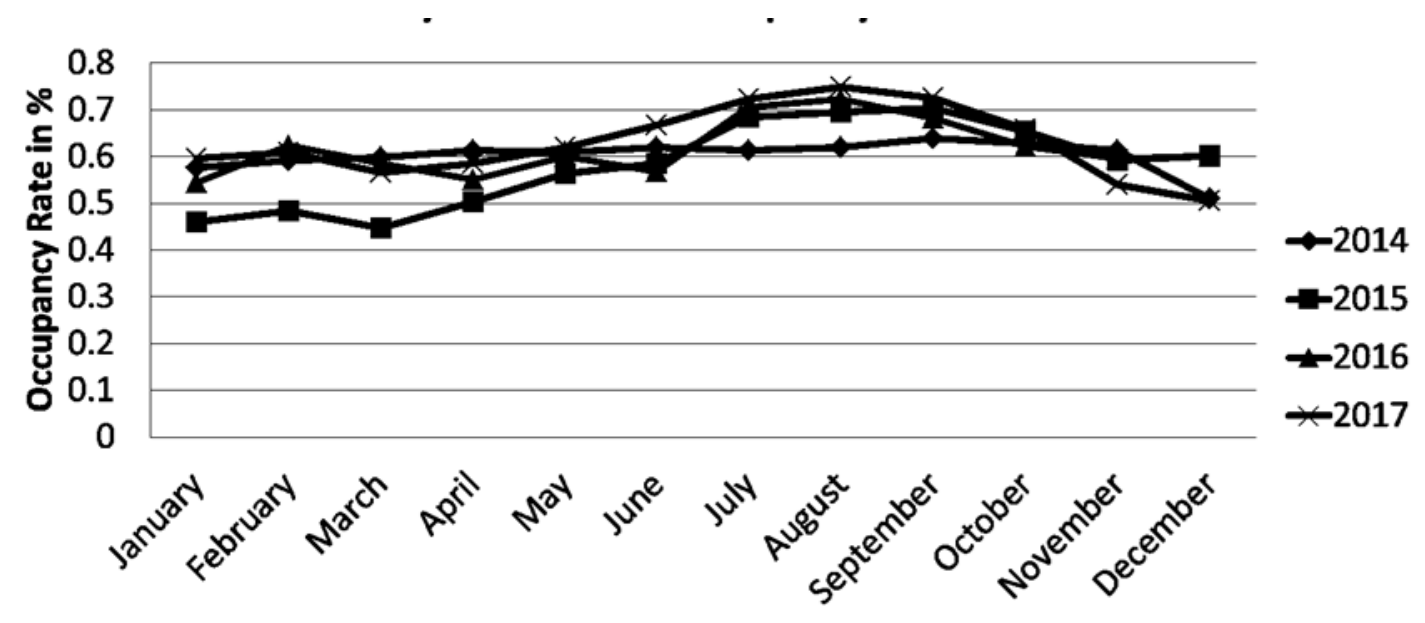

Source: Bali Government Tourism Office (2018)

Bali Government Tourism Office (2018) said that the accommodation and food and beverage supply sector contribute dominantly to the growth of the Balinese economy. This refers to Bali's economic growth figures, in the third quarter (JulySeptember) 2017, and per the same quarterly count in 2016. In both sessions the calculation, the accommodation and food and beverage supply sector dominated the growth of the Bali economy. In the third quarter of 2017, the economy of Bali grew 6.22 
percent. From these calculations it was revealed accommodation and food and beverage supply sector recorded the highest growth of 10.71 percent. Meanwhile, Bali is also the number one destination for MICE tourism in Indonesia. Meanwhile on the second place is Yogyakarta and Jakarta is in the third. MICE tourist expenditure value can be 7-8 percent higher than leisure tourists or who do come specifically for travel. Meeting, Incentive, Travel, and Conference (MICE), is one of the special interest tours that are intended for Business visitor groups. Bali has always been in the top ranking compared to 15 other MICE destinations in Indonesia. The highest ranking that Bali has ever received was in 2012 with 55 meetings, while others only had 40 meetings (Kusniarti, 2019).

Economically, Bali had stable local economic growth in the last several years. Bali's economy in the first quarter of 2018 increased in the range of between 5.80 percent and 6.2 percent. On the demand side, the performance improvement was mainly driven by an increase in household consumption performance in line with the provincial minimum wage increase (UMP) in 2018 (Kusniarti, 2019). The mapping for foreign tourists in Bali had been clearly recorded in data of Bali Bureau of Statistics (2020). These were 5 countries that acted as the biggest contributor for foreign tourists in Bali. Those countries were China (21 percent), Australia (19.5 percent), India (5.6 percent), Russia (4.8 percent) and South Korea (4.5 percent). When tourism entrepreneurs wanted to spend promotion budget to hit foreign tourist segment, it should be focused on those 5 countries as priority to achieve efficiency and effectiveness in promotion. The growth of tourists from China is significant on recently, therefore it needs special attention because their country economy is growing rapidly and if tourism entrepreneurs in Bali can adapt with Chinese tourists, they can gain huge financial advantage to sustain their business.

The potential market of Bali has been identified by entrepreneurs. Based on Single Investor Identification Number, the number of entrepreneur in Bali kept increasing up to 12.582 investors in 2018, which accounted for 17 percent increase from the 2017 which was 19.729 investors (Nabhani, 2018). Data from the Office of Cooperatives and Micro, Small and Medium Enterprises (MSMEs) of Bali Province recorded that the entrepreneurship ratio as of the end of December 2018 was 8.3 percent, higher than the national average which ranged from 4 to 5 percent in average, about 98 percent of all business in Bali fell into category of MSMEs. The number of MSMEs in Bali Province was 326.009 MSMEs spread in nine regencies or cities. This number increased by 13.042 or 4 percent compared to December 2017 data. 


\section{Graphic 2. Number of Micro, Small and medium Enterprises by Region in}

Bali

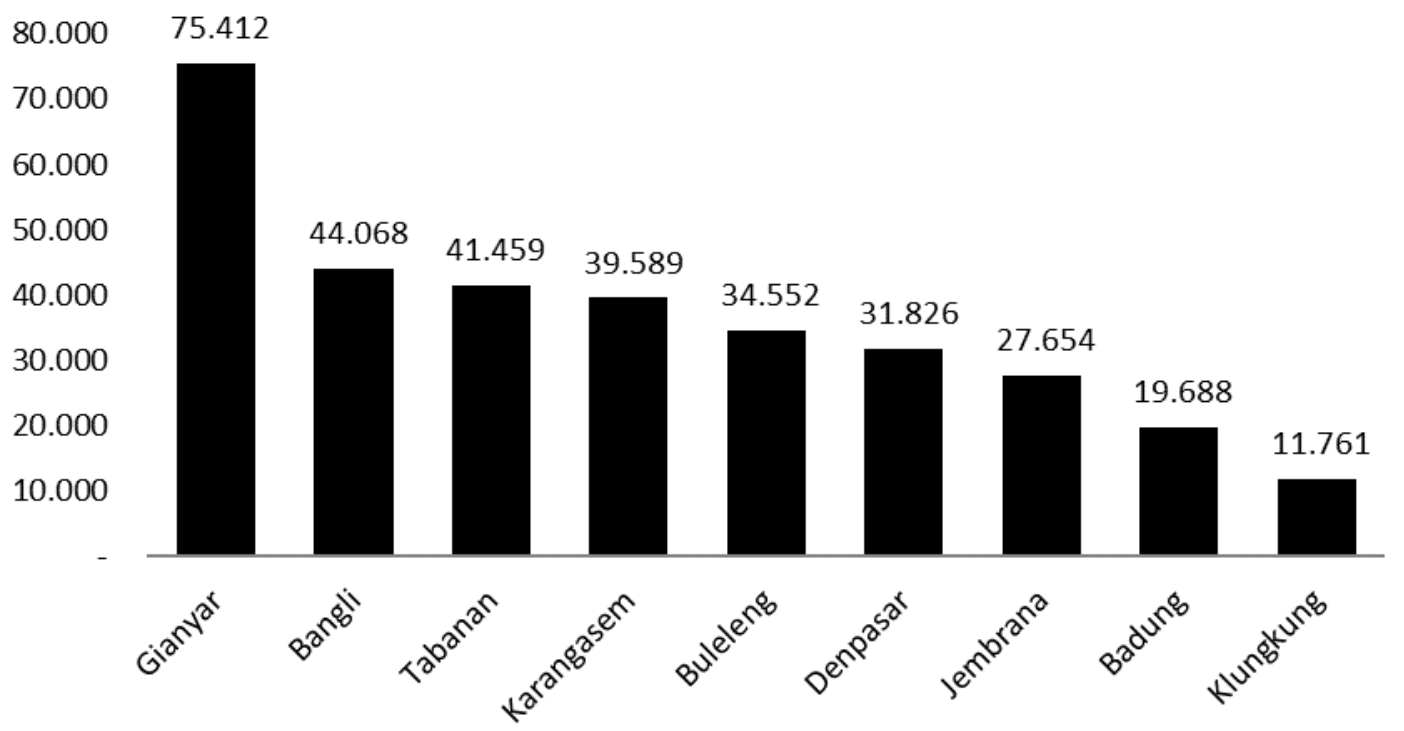

- Number of Micro, Small and medium Entreprises by Region in Bali

Source: Mardika (2019)

Gianyar becomes region with the highest number of MSMEs in Bali, followed by Bangli, Tabanan and Karangasem. Government in Gianyar provides training and access to working capital, which by far becomes main problem of small business to grow up. Therefore the region is attractive to entrepreneurs, especially in tourism industry (Mardika, 2019).

It is also worthy to note that seeing the high potentiality of entrepreneurship in Bali, government should help with this issue so that more investors can come and invest in business incubation or co-working space in Bali, this is because start-up companies or which is usually recognized as new entrepreneurs, are still lack of experience and therefore the possibility of their business failure is high, they need support and facility to adapt and strengthen their business model. Therefore, the need of co-working space was increasing. The number of co-working space all over Indonesia was increasing rapidly from 45 units in 2016 to 150 units in 2017 and 200 units registered on June 2018 (Setyowati, 2018). However, 80 percent of the co-working spaces and creative hubs were currently established in Java. Along with the development of infrastructure in the eastern part of Indonesia, e.g. Palapa Ring project. Therefore it should gain attention from government and investor to establish co-working space and creative hubs in Bali.

\section{Social}

Indonesia people are very communal therefore community development should be well managed because it can help entrepreneurs to make network, collaborate and introduce their product with one another (Putri, 2018). The power of recommendation and word of mouth must also be exploited to acquire new customer. About 83.5 percent of Balinese local people religion is Hindu and they apply caste system (World Population Review, 2020). All tourist and business must comply with Hindu culture. One 
implementation from this adaption process is that all businesses must be closed during Nyepi day (Retaduari, 2018). This culture is heavily applied in local neighbourhood. Therefore, foreign business in this high content island should learn and pay attention on adapting themselves to Hindu culture, in order to prevent public relation problem and cultural shock in business communication. Culture can help local entrepreneurs in Bali to market their product. Traditional culture and believe has an attractiveness that can motivate tourist to buy our product (Susilo, 2018).

Bali has a relatively low living cost, friendly people and good internet network, thus it can trigger a trend of working while having holiday which is called as digital nomad (Maulidia, 2017). Digital nomad is a trending way of how digital entrepreneurs work today. Unlike other entrepreneurs, digital nomad has more flexibility in choosing where they work and they can move anywhere they want as long as there is internet connection. Digital nomad entrepreneurs work by utilizing gadget and laptop. They communicate with their co-workers and client distantly. Bali is good place for digital nomad who wants to work while enjoying beautiful scenery and beaches.

\section{Technology}

Internet speed in Indonesia is considered slow compared to other countries, at 13.79 Mbps for cable internet and 9.82 Mbps for mobile internet compared to average of world internet speed which is 42.7 Mbps (Kurnia. 2018). It made Bali less competitive than other countries for digital nomad entrepreneurs whose work heavily depends on internet. Despite slow internet connection, a survey by the Indonesian Internet Service Providers Association, or APJII, Indonesia recorded 143.26 million internet users in 2017, which is 7.9 percent increased from 2016 and account for about 54.2 percent of total population (Yuniarni, 2018).

Finding place to stay in Bali is easy because of recent technology development. The appearance of innovative online rental service such Airbnb was trending and made market more competitive for hotel, therefore finding a cheaper place to stay in Bali became easier after online rental service entered the market. It can increase number of incoming visitors and bring positive impact to tourism industry. A study had revealed that 81 percent of leisure travellers prefer used internet to find room and 82 percent of business oriented travellers prefer used internet to find room when they visited new place which indicated that digital marketing is essential marketing tool for business in tourism sector in Bali (Google and MediaCT, 2012). Public transportation and traffic are not well developed and managed in Bali (Artika, 2014). There is only Trans Sarbagita bus rapid transit with limited route and vehicle. The alternative option for tourists are Grab, Uber and Gojek online transportation but its unclear regulation has caused a lot of conflict between them and traditional taxi drivers. Therefore, many room providers complete their service with airport pickup service.

\section{Environment}

Bali has environmental problem that creates opportunity for green entrepreneurship. Research showed that the water reservoir in Bali was only 20 percent left, which then suggested that Bali tends to have water crisis by 2020. Tourism industry and water consumption of commercial properties were blamed as factor of this. It is positive indication that green project in Bali will be supported by government and its native people. Bali also confirmed that they had emergency issue with waste. 
Graphic 3. Waste Generation by Region and Type in Bali

\begin{tabular}{|l|r|}
\hline \multicolumn{1}{|c|}{$\begin{array}{c}\text { Cities/Sub- } \\
\text { districts }\end{array}$} & $\begin{array}{c}\text { Waste } \\
\text { Generation } \\
\text { (ton/day) }\end{array}$ \\
\hline Badung & 523.6 \\
\hline Bangli & 210.3 \\
\hline Buleleng & 310.3 \\
\hline Gianyar & 180.4 \\
\hline Jembrana & 126.9 \\
\hline Karangasem & 129.4 \\
\hline Klungkung & 84.5 \\
\hline Tabanan & 177.4 \\
\hline Kota Denpasar & 590.3 \\
\hline Total & 2333.1 \\
\hline
\end{tabular}

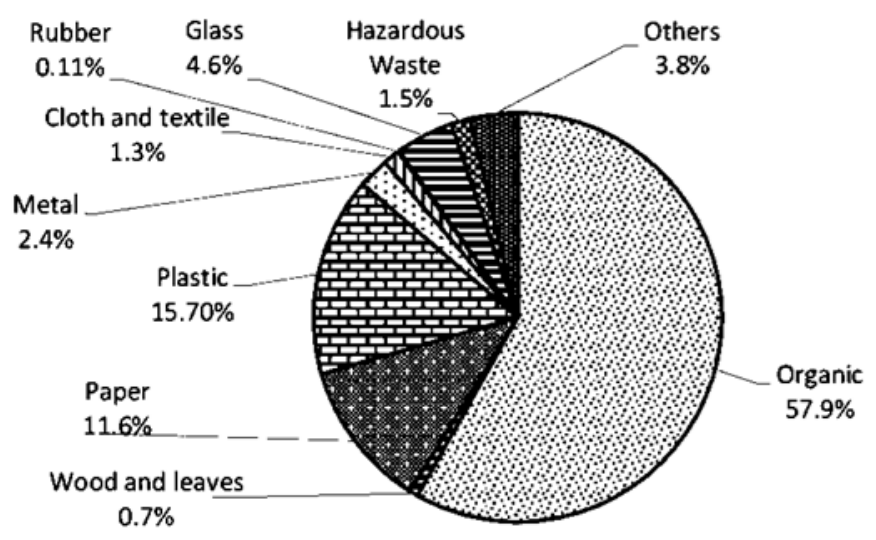

Source: Widyarsana., Damanhuri \& Agustina (2020)

Bali totally produced waste of about 2333.1 ton per day. The biggest portion comes from Badung with 523.6 ton waste generation per day, followed by Bangli, Buleleng, Gianyar and soon (please see graphic 3). When asked about the type of waste, it was found that 57.9 percent of waste in Bali is organic waste, while plastic waste was accounted for 15.70 percent and paper 11.6 percent. These three types of waste dominate, hence needs proper regulation from government and stakeholder in order to deal with it. Organic waste was relatively easier to recycle. Bali has urged all stakeholders to recycle organic waste into compost that is functioned as fertilizer for plants. The role model of this is State Electricity Enterprise in Bali that has its own recycling machine and produced $650 \mathrm{~kg}$ compost from 30 percent of its own organic waste (Kusniati, 2019).

Furthermore, Denpasar Mayor Regulation Number 36 Year 2018 about Reduction of Use of Plastic Bags came into force on January 1, 2019. According to the latest data it is said that the percentage decrease in the use of plastic bags was 54.26 percent for traditional markets and 86.27 percent, respectively. The Denpasar City Government has also issued Denpasar Mayor's Instructions No. 1 of 2018 on Waste Reduction which regulates the reduction of waste including plastic waste to the level of traditional markets and other business activities in Denpasar City (Supartika, 2019).

\section{Legal}

While discussing about protecting law in Bali, the business and consumer protection law in Bali was supportive. Indonesia had consumer protection law no 8/1999 and some national consumer protection organizations that were founded by government to protect right of customers by law. Bali also has a mediation legal institution with purpose to provide non-time consuming and easy conflict resolution between company and customer without going to court (The Indonesian Consumers Foundation, 2016). However, the regulation for co-working space in Indonesia was not still available. Therefore, the rule and taxation for new entrepreneurs were still unclear. In addition, for reference, co-working space in Jakarta was classified as virtual office which was regulated under SE PTSP DKI Jakarta Nomor 6 Tahun 2016 (Setyowati, 2018). 


\section{CONCLUSION}

Bali has good and competitive environment for tourism entrepreneurship. Governments actively promoted Bali as world class tourism destination. While at the same time provided grant for green project, through their investment coordinating board, governments also helped investor to enter Indonesia market easily and conveniently. In economic aspect, the growth of tourism industry is seasonal but prospective since the economic growth is visibly clear and stable. While setting up business in Bali needs basic knowledge in local Hindu culture, the technology infrastructure in Bali still needs improvement especially related to internet speed. Empowerment of Green project is important because Bali has significant environmental issue in recently, which also becomes opportunity for entrepreneurs to innovate. The protection law and legal standing to support entrepreneurship at general level is already available, however there is still need for improvement, especially related to start-up taxation and environmental issue, regulation for plastic garbage reduction must be empowered to deal with environmental issue. Further researcher is expected to understand more aspect of tourism industry in Bali to complete the literature. In addition, future research should be conducted in different research design, such as in quantitative design. 


\section{REFERENCES}

Aguilar, F. J. (1967). Scanning the business environment. Macmillan.

Ariyanti, F. (2015). RI Kini Total Bebaskan Visa Bagi 174 Negara. Retrieved from https://www.liputan6.com/bisnis/read/2395157/ri-kini-total-bebaskan-visabagi-174-negara

Artika, K. (2014). Bali Govt Plans to Build Rail Transport. Retrieved from http://www.thebalitimes.com/2014/12/09/bali-govt-plans-to-build-railtransport/

Bali Government Tourism Office. (2018) Rilis Data Statistik Januari 2018. Retrieved from https://disparda.baliprov.go.id/rilis-data-statistik-januari-2018/

Damanik, J \& Weber, H. (2006). Perencanaan Ekowisata Dari Teori Ke Aplikasi. Yogyakarta: Andi Affset

Dimyati, V. (2019). Mengenal 10 Destinasi Bali Baru, Wisata Prioritas yang Jadi Urusan Wishnutama. Retrieved from https://www.inews.id/travel/destinasi/mengenal10-destinasi-bali-baru-wisata-prioritas-yang-jadi-urusan-wishnutama

Fauzie, Y. Y (2017). Jokowi Terbitkan Perpres Kemudahan Berusaha. Retrieved from https://www.cnnindonesia.com/ekonomi/20171010182513-92-

247471/jokowi-terbitkan-perpres-kemudahan-berusaha/

Google, \& MediaCT, I. (2012). The 2012 Traveller. from http://www.biggestleaf.com/wp-content/uploads/2012_the-2012-traveler.pdf

Gumelar, G. (2015). BKPM Optimistis Investasi Hijau Tembus Rp 1.297 Triliun. CNN. Indonesia. Retrieved from https://www.cnnindonesia.com/ekonomi/20150427104356-92-49425/2019bkpm-optimistis-investasi-hijau-tembus-rp-1297-triliun

Indonesian Consumers Foundation. (2020). Retrieved from https://ylki.or.id/2016/12/pelembagaan-perlindungan-konsumen/

Irawan, D. (2018). Presiden Minta Perguruan Tinggi Sediakan Co Working Space dan Creative Hub. Kabar24. Retrieved from http://kabar24.bisnis.com/read/20180202/255/733648/presiden-mintaperguruan-tinggi-sediakan-co-working-space-dan-creative-hub

Kurnia, T. (2018). Rata-rata Kecepatan Internet Dunia 42,7 Mbps, Indonesia?. Liputan 6. Retrieved from https://www.liputan6.com/tekno/read/3466585/rata-ratakecepatan-internet-dunia-427-mbps-indonesia

Kusniarti, A. A. S. (2019). PLN UID Bali Rintis Pengelolaan Sampah Organik. Retrieved from https://bali.tribunnews.com/2019/12/26/pln-uid-bali-rintis-pengelolaansampah-organik.

Kusniarti, A.A.S (2019). Mice Bisa Jadi Alternatif Dongkrak Pariwisata. Retrieved from https://bali.tribunnews.com/2019/11/08/mice-bisa-jadi-alternatif-dongkrakpariwisata

Law of the Republic Of Indonesia Number 8 Year 1999 Concerning Consumer Protection. 2020. Retrieved from https://aseanconsumer.org/file/pdf_file/04 percent20Law-No.-8-Concerning-Consumer-Protection.pdf

Mardika, I. N. (2019). Jumlah Wirausahawan di Bali Meningkat jadi 326.000 UMKM. Retrieved from https://www.beritasatu.com/ekonomi/541035-jumlahwirausahawan-di-bali-meningkat-jadi-326000-umkm

Maulidia, R. (2017). Digital Nomad, Trend Liburan Sambil Bekerja di Bali. Retrieved from https://akurat.co/id-150642-read-digital-nomad-trend-liburan-sambilbekerja-di-bali

Milla, H. (2013). Pendidikan Kewirausahaan: Sebuah Alternatif Mengurangi Pengangguran Terdidik Dan Pencegahan Korupsi. Jurnal Al-Ta'lim, 465-47

Nabhani, A. (2018). OJK Genjot Pertumbuhan Investor Lokal - Potensi Ekonomi di Bali Besar. Neraca. Retrieved from http://www.neraca.co.id/article/104348/ojkgenjot-pertumbuhan-investor-lokal-potensi-ekonomi-di-bali-besar 
Parwata, I.B.M. (2018). Masuk Shio Anjing, Bali Pasang Target Datangkan Investasi Rp 18,37 T. Retrieved from https://radarbali.jawapos.com/read/2018/01/12/39928/masuk-shio-anjingbali-pasang-target-datangkan-investasi-rp-1837-t

Putri, E. (2018). 11 Things You Should Know About Indonesian Culture. Culture Trip. Retrieved from https://theculturetrip.com/asia/indonesia/articles/11-thingsyou-should-know-about-indonesian-culture/

Ramadhiani, A. (2018). Tekanan Berlanjut, Hotel Bintang 3 di Bali Makin Menyusut. Kompas. $\quad$ Retrieved from https://properti.kompas.com/read/2018/02/13/083331421/tekananberlanjut-hotel-bintang-3-di-bali-makin-menyusut

Reginald, A. R., \& Mawardi, I. (2014). Kewirausahaan Sosial Pada Pondok Pesantren Sidogiri Pasuruan. Jurnal Ekonomi Syariah Teori dan Terapan, 333-345

Retaduari, E. A. (2018). Hari Raya Nyepi, Bali Silent hingga Pukul 06.00 Esok. Detik News. Retrieved from https://news.detik.com/berita/d-3921710/hari-rayanyepi-bali-silent-hingga-pukul-0600-esok

Setyowati, D. (2018). Jumlah Coworking Space Melonjak meski Terkendala Regulasi. Katadata.co.id. Retrieved from https://katadata.co.id/berita/2018/06/26/jumlah-coworking-space-melonjakmeski-terkendala-regulas

Supartika, P. (2019). Di Bali, Ada 5 Peraturan yang Mengatur tentang Sampah Plastik. Retrieved from https://bali.tribunnews.com/2019/12/03/di-bali-ada-5peraturan-yang-mengatur-tentang-sampah-plastik.

Susilo, D. (2018). Sacralisation Marketing Strategy (Innovative Branding for Indonesian Local Culture). BISE: Jurnal Pendidikan Bisnis dan Ekonomi, 4(1).

Think with Google. (2016). Travel trends 2016: Data reveals hot spots and new consumer insights. Retrieved from https://www.thinkwithgoogle.com/advertising-channels/mobilemarketing/travel-trends-2016-data-consumer-insights/

Widyarsana, I. M. W., Damanhuri, E., \& Agustina, E. (2020). Municipal solid waste material flow in Bali Province, Indonesia. Journal of Material Cycles and Waste Management, 22(2), 405-415.

Williams, K. (2010). Brilliant Business Plan. Prentice Hall, New Jersey

World Population Review. Bali Population 2020. (2020). Retrieved from https://worldpopulationreview.com/world-cities/bali-population/

Yuniarni, S. (2018). Indonesia Had 143m Internet Users in 2017: APJII. Jakarta Globe. Retrieved from http://jakartaglobe.id/business/indonesia-143m-internetusers-2017-apjii/ 